\title{
Central 5-HT Neurotransmission Modulates Weight Loss following Gastric Bypass Surgery in Obese Individuals
}

\author{
M.E. Haahr, ${ }^{1,2}$ D.L. Hansen, ${ }^{3}$ P.M. Fisher, ${ }^{1,2}$ C. Svarer, ${ }^{1,2}$ D.S. Stenbæk, ${ }^{1,2}$ K. Madsen, ${ }^{1,2}$ J. Madsen, ${ }^{6}$ J.J. Holst, ${ }^{7}$ \\ W.F.C. Baaré, ${ }^{2,4}$ L. Hojgaard, ${ }^{6}$ T. Almdal, ${ }^{5}$ and G.M. Knudsen ${ }^{1,2}$ \\ ${ }^{1}$ Neurobiology Research Unit, Rigshospitalet, 2100 Copenhagen, Denmark, ${ }^{2}$ Center for Integrated Molecular Brain Imaging, Rigshospitalet and University \\ of Copenhagen, 2100 Copenhagen, Denmark, ${ }^{3}$ Department of Endocrinology and ${ }^{4}$ Danish Research Centre for Magnetic Resonance, Hvidovre Hospital, \\ 2650 Hvidovre, Denmark, ${ }^{5}$ Steno Diabetes Center, 2820 Gentofte, Denmark, ${ }^{6}$ PET and Cyclotron Unit, Rigshospitalet and University of Copenhagen, 2100 \\ Copenhagen, Denmark, and 7The NNF Center for Basic Metabolic Research, Department of Biomedical Sciences, University of Copenhagen, 2100 \\ Copenhagen, Denmark
}

The cerebral serotonin (5-HT) system shows distinct differences in obesity compared with the lean state. Here, it was investigated whether serotonergic neurotransmission in obesity is a stable trait or changes in association with weight loss induced by Roux-in-Y gastric bypass (RYGB) surgery. In vivo cerebral 5- $\mathrm{HT}_{2 \mathrm{~A}}$ receptor and 5- $\mathrm{HT}$ transporter binding was determined by positron emission tomography in 21 obese [four men; body mass index (BMI), $40.1 \pm 4.1 \mathrm{~kg} / \mathrm{m}^{2}$ ] and 10 lean (three men; BMI, $24.6 \pm 1.5 \mathrm{~kg} / \mathrm{m}^{2}$ ) individuals. Fourteen obese individuals were re-examined after RYGB surgery. First, it was confirmed that obese individuals have higher cerebral 5-HT ${ }_{2 \mathrm{~A}}$ receptor binding than lean individuals. Importantly, we found that higher presurgical 5- $\mathrm{HT}_{2 \mathrm{~A}}$ receptor binding predicted greater weight loss after RYGB and that the change in 5- $\mathrm{HT}_{2 \mathrm{~A}}$ receptor and 5-HT transporter binding correlated with weight loss after RYGB. The changes in the 5-HT neurotransmission before and after RYGB are in accordance with a model wherein the cerebral extracellular 5-HT level modulates the regulation of body weight. Our findings support that the cerebral 5-HT system contributes both to establish the obese condition and to regulate the body weight in response to RYGB.

Key words: 5 -HT; 5 - $\mathrm{HT}_{2 \mathrm{~A}}$ receptor; 5-HT transporter; bariatric surgery; positron emission tomography

\section{Introduction}

Obesity represents one of the greatest challenges in the plentiful modern societies. When energy-dense food is effortlessly available, a large percentage of humans tend to eat more than metabolically required. The health consequences are severe as obesity is associated with increased morbidity and mortality because of cardiovascular diseases, diabetes, cancer, osteoarthritis, liver and kidney disease, sleep apnea, and depression (Pi-Sunyer, 2009).

In humans, rigid homeostatic mechanisms prevent sustained weight loss, regardless of body weight (Berthoud et al., 2012). Consequently, obese people are often unsuccessful in acquiring or maintaining a sustained weight loss, and bariatric surgery is currently the only treatment of obesity that significantly reduces

\footnotetext{
Received Aug. 10, 2014; revised March 3, 2015; accepted March 4, 2015

Author contributions: M.E.H., D.L.H., T.A., and G.M.K. designed research; M.E.H., D.L.H., D.S.S., J.M., J.J.H., and T.A. performed research; C.S., K.M., J.M., J.J.H., W.F.C.B., and L.H. contributed unpublished reagents/analytic tools; M.E.H., P.M.F., C.S., J.J.H., and G.M.K. analyzed data; M.E.H., P.M.F., and G.M.K. wrote the paper.

This work was supported by the Lundbeck Foundation; the Novo Nordic Foundation; the Danish Agency for Science, Technology, and Innovation; and the University of Copenhagen. We thank the study participants. We thank Aleris-Hamlet Hospitals for participating in the recruitment process of this study. We gratefully acknowledge The John and Birthe Meyer Foundation for the donation of the Cyclotron and PET scanner and the Toyota Foundation for the donation of the HPLC equipment.

The authors declare no competing financial interests.

Correspondence should be addressed to Gitte Moos Knudsen, Neurobiology Research Unit, Section 6931, 9 Blegdamsvej, DK-2100 Copenhagen, Denmark. E-mail: gmk@nru.dk.

DOI:10.1523/JNEUROSCI.3348-14.2015

Copyright $\odot 2015$ the authors $\quad 0270-6474 / 15 / 355884-06 \$ 15.00 / 0$
}

long-term morbidity and mortality. Roux-en-Y gastric bypass (RYGB) is one of the most efficient surgical methods, but for unknown reasons, the success of weight loss varies among RYGB patients, and some patients fail to achieve substantial weight loss (le Roux et al., 2007).

The serotonin (5-HT) system and its role in feeding has been studied for decades in animals, and numerous studies show that the predominant effect of enhanced serotonergic neurotransmission is increased satiety, reduction of energy expenditure, and body weight (Donovan and Tecott, 2013). The effect is possibly connected to the signaling of the neuroendocrine substance GLP-1 (Asarian, 2009), which is suggested to play a key role in mediating the increased satiety after RYGB (Docherty and le Roux, 2014). Only few studies have researched the serotonergic neurotransmission in obese humans, but recent data suggest that the 5-HT level in nucleus accumbens is inversely related to body weight (Haahr et al., 2012, 2014). Low 5-HT levels may thus lead to increased food intake. The $5-\mathrm{HT}_{2 \mathrm{~A}}$ receptor $\left(5-\mathrm{HT}_{2 \mathrm{~A}} \mathrm{R}\right)$ is a postsynaptic receptor densely located in neocortex (Adams et al., 2004), whereas the 5-HT transporter (5-HTT) is situated presynaptically and mainly in the subcortical structures (Erritzoe et al., 2010b). In two large independent cohorts of humans, we have seen a positive association between body mass index (BMI) and the neocortical 5- $\mathrm{HT}_{2 \mathrm{~A}} \mathrm{R}$ binding (Adams et al., 2004; Erritzoe et al., 2009) and a negative association between BMI and subcortical 5-HTT binding (Erritzoe et al., 2010b), as measured with in vivo 
positron emission tomography (PET) brain imaging. These observations were also made in a polygenetic rat model of obesity (Ratner et al., 2012). These cross-sectional studies do not, however, resolve whether alterations in the 5-HT system are causes or consequences of obesity. Accordingly, the main goal of this prospective intervention study was to determine whether altered serotonergic neurotransmission is a stable trait of obesity, consistent with a causal role, or whether it is influenced by the intervention and subsequent weight loss, indicating that it is a consequence of obesity.

We conducted PET brain imaging with the radioligands $\left[{ }^{18} \mathrm{~F}\right]$ altanserin and $\left[{ }^{11} \mathrm{C}\right] \mathrm{DASB}$ and assessed the $5-\mathrm{HT}_{2 \mathrm{~A}} \mathrm{R}$ and 5-HTT availability in lean and in obese individuals before and after RYGB. Self-reported satiety sensation and GLP-1 levels were measured presurgically and postsurgically and were related to BMI and the 5-HT marker levels. We expected to replicate the previously found differences in cerebral $5-\mathrm{HT}_{2 \mathrm{~A}} \mathrm{R}$ and $5-\mathrm{HTT}$ levels between obese and lean individuals and hypothesized that weight loss after RYGB would be associated with a normalization of cerebral $5-\mathrm{HT}_{2 \mathrm{~A}} \mathrm{R}$ and 5-HTT binding. Moreover, we predicted that the presurgical 5- $\mathrm{HT}_{2 \mathrm{~A}} \mathrm{R}$ and 5-HTT levels and the change in the two markers would be associated with the success of weight loss after RYGB.

\section{Materials and Methods}

Participants. Twenty-one obese adult individuals (four men) with BMI $>35 \mathrm{~kg} / \mathrm{m}^{2}$, approved and signed up for RYGB, were recruited from the Department of Endocrinology, Hvidovre University Hospital, Denmark $(n=20)$, or from Alleris-Hamlet Hospitals, Denmark $(n=1)$. Ten ageand gender-matched lean (BMI, $<27 \mathrm{~kg} / \mathrm{m}^{2}$ ), healthy individuals (three men) were recruited from public advertisements. After the study aim and design had been explained, written informed consent was obtained from each participant according to the declaration of Helsinki II. The study was approved by the Ethical Committee of Copenhagen [protocol (KF) 01 2006-20 with amendment 18574].

The participants were initially screened for the following exclusion criteria: neurological or psychiatric disease according to ICD-10; uncontrolled cardiovascular or endocrine disease; any use of illicit drugs within the last 3 months, or lifetime use $>10$ times; use of prescribed antiobesity medication, such as Rimobant, Orlistat, or Sibutramine; use of selective serotonin reuptake inhibitors (SSRI) for the last 8 months; and previous or current use of medication that significantly affects brain function (e.g., limited use of NSAIDs was permitted). Moreover, participants underwent the modified version of the semistructured interview Eating Disorder Examination to exclude participants with DSM-IVdefined symptoms of binge eating disorder.

The participants were examined by a physician and had a normal physical and neurological examination. They also had unremarkable blood screens and structural MRI of the brain. To assess symptoms of stress, psychopathology, and depression, the participants filled in the SCL-90-R, the Major Depression Index, and Cohen's Perceived Stress. IQ was investigated with two subscales (the number series and verbal analogies) of the Intelligenz-Struktur-Test $2000 \mathrm{R}$.

Before arrival at the PET facility, the RYGB participants fasted for $12 \mathrm{~h}$, and after arrival, they were served a mixed $400 \mathrm{kcal}$ breakfast. We measured satiety (with the question: How full are you?) on a visual analog scale and collected venous blood for measurement of the gut hormone GLP-1 at 30 and $0 \mathrm{~min}$ before the meal and at 15,30,45,60,90, and $120 \mathrm{~min}$ after the meal.

PET imaging. The Siemens HRRT PET scanner with an approximate in-plane resolution of $1.5 \mathrm{~mm}$ was used (Olesen et al., 2009). The scans were reconstructed using iterative reconstruction with attenuation map improvements. If head motion amounted to $>3 \mathrm{~mm}$, the PET frames were corrected for intrascan movement by using the scaled least-squares cost function in AIR (version 5.2.5).

$\left[{ }^{18} \mathrm{~F}\right]$ altanserin was administrated as a combination of a bolus injection and a continuous infusion to produce tracer steady state in tissue and blood. The bolus component was worth $1.75 \mathrm{~h}$ of constant infusion, and participants received a maximum of $3.7 \mathrm{MBq} / \mathrm{kg}$ body weight $\left[{ }^{18} \mathrm{~F}\right]$ altanserin. During constant infusion of $\left[{ }^{18} \mathrm{~F}\right]$ altanserin, a $40 \mathrm{~min}$ PET scan (five frames of $8 \mathrm{~min}$ ) was performed starting $2 \mathrm{~h}$ after bolus injection, and five midframe venous blood samples were drawn for determination of the metabolite-corrected plasma fraction of $\left[{ }^{18} \mathrm{~F}\right]$ altanserin. For $\left[{ }^{11} \mathrm{C}\right] \mathrm{DASB}$, a dynamic $90 \mathrm{~min}$ emission recording (36 frames, increasing progressively in duration from $10 \mathrm{~s}$ to $10 \mathrm{~min}$ ) was initiated immediately after a $20 \mathrm{~s}$ intravenous injection.

The outcome parameter for $\left[{ }^{18} \mathrm{~F}\right]$ altanserin binding was the binding potential of specific tracer binding $\left(\mathrm{BP}_{\mathrm{P}}\right)$. Cerebellum was used as a reference region because it represents nondisplaceable binding only. In steady state, the $\mathrm{BP}_{\mathrm{P}}$ is defined as follows:

$$
\mathrm{BP}_{\mathrm{P}}=\left(C_{\mathrm{VOI}}-C_{\mathrm{ND}}\right) / C_{\mathrm{P}}=\left(f_{\mathrm{P}} \times B_{\text {avail }}\right) / K_{\mathrm{d}},
$$

where $C_{\mathrm{VOI}}$ and $C_{\mathrm{ND}}$ are steady-state mean count concentrations in the volume of interest (VOI) and in the reference region, respectively; $C_{\mathrm{P}}$ is the steady-state concentration of nonmetabolized radiotracer in plasma; $f_{\mathrm{P}}$ is the free fraction of radiotracer; $B_{\text {avail }}$ is the density of receptor sites available for tracer binding; and $K_{\mathrm{d}}$ is the affinity constant of the radiotracer to the receptor.

The outcome parameter of the cerebral $\left[{ }^{11} \mathrm{C}\right] \mathrm{DASB}$ binding within a brain region is the nondisplaceable binding potential, designated $\mathrm{BP}_{\mathrm{ND}}$. The $\mathrm{BP}_{\mathrm{ND}}$ was calculated for the VOIs using the cerebellum input as the reference region with nonspecific binding. We used a modified reference tissue model designed specifically for quantification of $\left[{ }^{11} \mathrm{C}\right] \mathrm{DASB}$ (MRTM/MRTM2) as described and evaluated by Ichise et al. (2003) using the software PMOD (version 3.0).

Magnetic resonance imaging. High-resolution, 3D T1-weighted MPRAGE and T2-weighted Turbo Spin Echo structural MR images were acquired in all participants, using a Siemens Magnetom Trio 3T MR scanner, and used for segmentation and brain-masking. RYGB participants underwent brain MRI scans both before and after RYGB. The interval between MRI and PET scans was $12 \mathrm{~d}(6-27)$ [median (interquartile range (IQR)].

Volumes of interest. Mean emission images from the brain PET scans were automatically aligned to the same individual's corresponding MRI using SPM5. Accurate coregistration was confirmed by visual inspection across all planes. VOIs were automatically delineated on each individual's transaxial MRI slices in a strictly user-independent manner, as described previously (Erritzoe et al., 2010b).

Our primary VOIs included those that previously had been identified as being associated with BMI, i.e., neocortex for $5-\mathrm{HT}_{2 \mathrm{~A}} \mathrm{R}$ binding (Erritzoe et al., 2009) and the combined caudate, putamen, and thalamus for 5-HTT binding (Erritzoe et al., 2010b).

GLP-1 measurements. Venous blood was collected into chilled EDTA tubes and immediately cooled on ice and centrifuged at $4^{\circ} \mathrm{C}$. Plasma was stored at $-20^{\circ} \mathrm{C}$ until analyzed. Plasma samples were assayed for total GLP-1 immunoreactivity as described previously (Orskov et al., 1994) using a radioimmunoassay (antiserum 89390) specific for the $C$ terminal of the GLP-1 molecule and reacting equally with intact GLP-1 and the primary (N-terminally truncated) metabolite.

Participant flow and intervention. Twenty-one obese and 10 lean individuals were included in the baseline examinations. The intervention was a standard laparoscopic RYGB technique, resulting in a gastric pouch with a volume of $\sim 25 \mathrm{ml}$, a $100 \mathrm{~cm}$ Roux limb, and a $75 \mathrm{~cm}$ biliopancreatic limb. Three participants failed to meet the requirement of an $8 \%$ preoperative weight loss and were not offered RYGB. Additionally, four obese participants did not complete the post-RYGB follow-up: three participants opted for the postsurgical PET scan out, and one individual could not be reinvestigated because of severe postsurgical complications. We did, however, obtain the postsurgical BMI for three of them. Thus, fourteen of the obese individuals were investigated twice, as they underwent RYGB 3.1 months (1.8-6.0) [median (IQR)] after the baseline PET scan and were reinvestigated 8.2 months (7.5-8.5) [median (IQR)] after RYGB. Because of problems with radiotracer production, HPLC determinations, or scanner issues, $\left[{ }^{18} \mathrm{~F}\right]$ altanserin PET failed in one obese individual at baseline and in two individuals after RYGB and for 


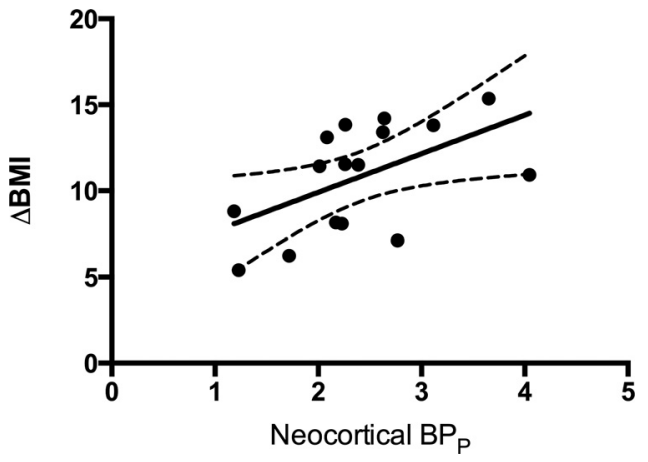

Figure 1. The estimated correlation (with $95 \%$ confidence intervals) between neocortical $5-\mathrm{HT}_{2 \mathrm{~A}} \mathrm{R}$ binding $\left(\mathrm{BP}_{\mathrm{p}}\right)$ before $\mathrm{RYGB}$ and weight loss after RYGB. $\triangle \mathrm{BMI}=\mathrm{BMI}_{\text {pre }}-\mathrm{BMI}_{\text {post }}$.

$\left[{ }^{11} \mathrm{C}\right] \mathrm{DASB}$ in one individual after RYGB. Altogether, we completed 31 baseline $\left[{ }^{11} \mathrm{C}\right] \mathrm{DASB}$ and $30\left[{ }^{18} \mathrm{~F}\right]$ altanserin PET scans of which 10 were in lean individuals. Twelve $\left[{ }^{18} \mathrm{~F}\right]$ altanserin and $13\left[{ }^{11} \mathrm{C}\right] \mathrm{DASB}$ PET follow-up scans were available for analysis.

Statistics. Statistically significant differences between unpaired or paired outcomes were evaluated with the appropriate two-tailed $t$ test (paired, unpaired, or Welch's $t$ test) or nonparametric tests (MannWhitney $U$ or Wilcoxon's tests), when the data were not normally distributed according to D'Agostino and Pearson's normality test. Gender differences were evaluated with the $\chi^{2}$ test.

Demographic, psychiatric, and PET data were compared between the age- and gender-matched obese and lean individuals and within individuals before and after RYGB. Additionally, linear regressions were used to assess the association between the pre-RYGB PET binding and the change in BMI achieved after RYGB and to model the association between the change in PET binding and the change in BMI. The time from RYGB to follow-up PET scans was included in the models but eliminated if the contribution to the model was statistically insignificant. The association between $5-\mathrm{HT}_{2 \mathrm{~A}} \mathrm{R}$ binding in neocortex and 5-HTT binding in caudate-putamen-thalamus was modeled as described previously (Erritzoe et al., 2010a) using up to three polynomials.

Measures of appetite and the GLP-1 response before and after RYGB were both generated by determining the area under the curve over a $2.5 \mathrm{~h}$ period before and after a meal. A comparison was made between the appetite scores and the GLP-1 response before and after RYGB, and, moreover, the change in the two scores was tested for associations with the change in BMI and the 5-HT marker changes.

A two-sided $p$ level of 0.05 was considered significant in all analyses, and the software used for statistical analyses was StatPlus:mac (AnalystSoft) or Prism 6 for Mac (GraphPad Software).

\section{Results}

Regression analyses revealed that pre-RYGB neocortical $5-\mathrm{HT}_{2 \mathrm{~A}} \mathrm{R}$ binding predicted weight loss (in BMI units, $\mathrm{kg} / \mathrm{m}^{2}$ ) achieved after RYGB $\left(F_{(1,14)}=6.012, p=0.028\right.$; Fig. 1$)$. No such association was seen between pre-RYGB 5-HTT binding and weight loss $\left(F_{(1,11)}=2.55, p=0.14\right)$.

In accordance with previous findings (Adams et al., 2004; Erritzoe et al., 2009), neocortical 5- $\mathrm{HT}_{2 \mathrm{~A}} \mathrm{R}$ binding $\left(\mathrm{BP}_{\mathrm{P}}\right)$ was significantly higher in obese $(2.53 \pm 0.95)$ relative to lean $(1.82 \pm 0.46$; $t_{(28.0)}=2.74 ; p=0.011$, Welch's $t$ test; Figs. 2,3$)$ individuals. This observation was confirmed when taking $f_{\mathrm{p}}$ into account; $\mathrm{BP}_{\mathrm{f}}$ was higher in obese compared with lean individuals $(p=0.008)$, and no correlation was seen between $\mathrm{BP}_{\mathrm{p}}$ and $f_{\mathrm{p}}(p=0.48)$. The $5-\mathrm{HT}_{2 \mathrm{~A}} \mathrm{R} \mathrm{BP}$ pinding remained higher in the obese individuals relative to the lean individuals after $\operatorname{RYGB}\left(t_{(19.9)}=2.16 ; p=\right.$ 0.043 , unpaired $t$ test; Fig. 2). No significant differences were found between presurgical and postsurgical $5-\mathrm{HT}_{2 \mathrm{~A}} \mathrm{R}$ binding $\left(2.44 \pm 0.76\right.$ vs $2.31 \pm 0.60 ; t_{(11.0)}=0.76 ; p=0.46$, paired $t$ test $)$. Subcortical 5-HTT $\mathrm{BP}_{\mathrm{ND}}$ did not differ statistically significantly

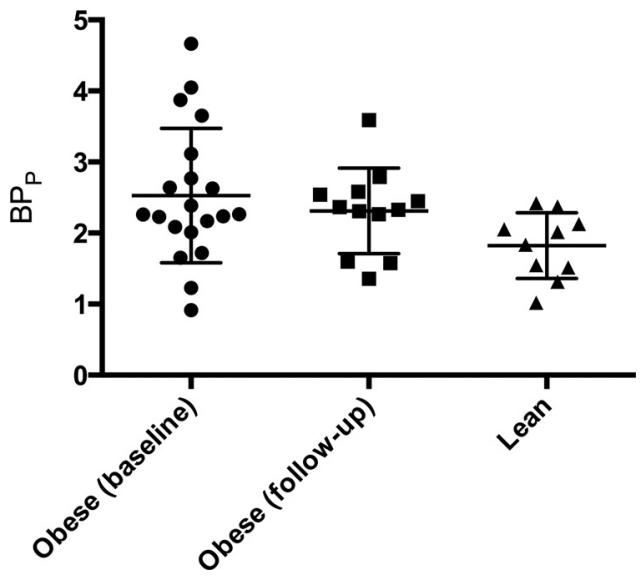

Figure 2. Neocortical $5-H_{2 A} R$ binding $(B P$ ) in pre- $R Y G B$, post-RYGB, and lean individuals. Bars show the mean and SDs for the three groups.

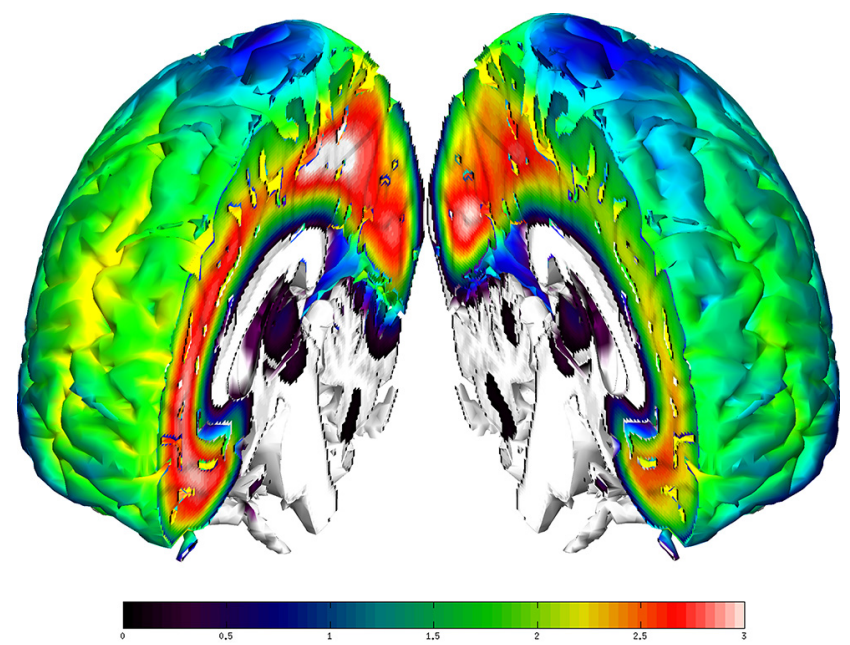

Figure 3. Differences in mean $5-\mathrm{HT}_{2 \mathrm{~A}} \mathrm{R}$ binding across neocortex in obese (left) and healthy (right) individuals. The color bar represents binding potential $\left(\mathrm{BP}_{\mathrm{p}}\right)$. The image was generated using parametric maps generated using PXMOD and normalized into Montreal Neurological Institute (MNI) space using SPM8 (failed for two obese individuals whose data were not included). After smoothing mean $\mathrm{BP}_{\mathrm{p}}$, maps were computed for each group and projected onto a T1 image in MNI space using a software package developed at the Neurobiology Research Unit, Rigshospitalet.

between obese $(2.09 \pm 0.35)$ and lean $\left(1.99 \pm 0.34 ; t_{(29.0)}=0.76\right.$; $p=0.46$, unpaired $t$ test) individuals, and no significant differences were found between presurgical and postsurgical 5-HTT binding $\left(2.16 \pm 0.34\right.$ vs $2.16 \pm 0.33 ; t_{(12.0)}=0.003 ; p=0.998$, paired $t$ test).

The changes in 5- $\mathrm{HT}_{2 \mathrm{~A}} \mathrm{R}$ and 5-HTT binding after RYGB were significantly correlated to the change in $\mathrm{BMI}\left(5-\mathrm{HT}_{2 \mathrm{~A}} \mathrm{R}: F_{(1,9)}=\right.$ $6.14, p=0.035$; 5-HTT: $F_{(1,9)}=22.61, p=0.001$; Fig. 4$)$. The finding illustrates that $5-\mathrm{HT}_{2 \mathrm{~A}} \mathrm{R}$ or 5 -HTT upregulation was associated with a smaller weight loss, whereas downregulation was associated with a larger weight loss. The time from RYGB to follow-up PET scans was included in the latter models, but since this variable did not contribute to the model $(p>0.63)$, the variable was excluded from the model.

We also investigated the intercorrelation between the $5-\mathrm{HT}_{2 \mathrm{~A}} \mathrm{R}$ and the 5-HTT in this sample of lean and obese (before and after RYGB) individuals. Our data clearly supported a second-order polynomial relationship, based on Akaike's information criterion, and, accordingly, we reproduced in an inde- 


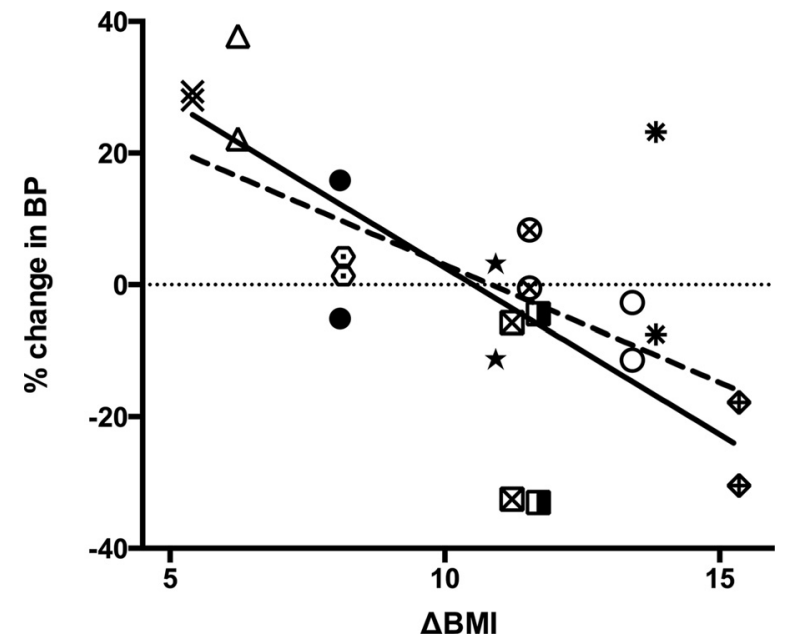

Figure 4. RYGB induced change in BMI versus change in binding potential for cerebral $5-\mathrm{HT}_{2 \mathrm{~A}} \mathrm{R}$ and $5-\mathrm{HTT}$ in individuals with both $\left[{ }^{11} \mathrm{C}\right] \mathrm{DASB}$ PET and $\left[{ }^{18} \mathrm{~F}\right]$ altanserin PET rescans (dashed line, 5- $\mathrm{HT}_{2 \mathrm{~A}} \mathrm{RBP} \mathrm{P}_{\mathrm{p}}$; solid line, 5- $\mathrm{HTT} \mathrm{BP}_{\mathrm{ND}}$ ). Each symbol indicates the 5- $\mathrm{HT}_{2 \mathrm{~A}}$ and 5-HTT levels in the individual persons. The open triangle represents the $5-\mathrm{HT}_{2 \mathrm{~A}} \mathrm{R}$ and the $5-\mathrm{HTT}$ change in one single individual associated with the change in BMl in that same individual; $\%$ change in $\mathrm{BP}$ is the percentage change in the specific radiotracerbinding defined as $\left[\left(\mathrm{BP}_{\text {post }} / \mathrm{BP}\right.\right.$ pre $\left.\left.)-1\right) \times 100\right]$; and $\triangle \mathrm{BMI}$ is the BMl after surgery subtracted by the BMl before surgery.

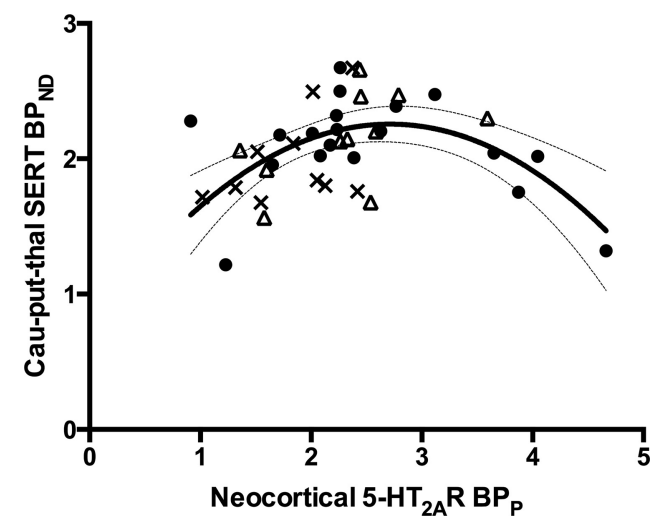

Figure 5. The solid line represents the estimated quadratic relationship between neocortical $5-\mathrm{HT}_{2 \mathrm{~A}} \mathrm{R}$-specific radiotracer binding $\left(\mathrm{BP}_{\mathrm{P}}\right)$ and subcortical (caudate, putamen, and thalamus) 5-HTT-specific radiotracer binding ( $\left.\mathrm{BP}_{\mathrm{ND}}\right)$. The $95 \%$ confidence interval is represented by the thin lines. Black dots, Pre-RYGB participants; crosses, lean participants; open triangles, postRYGB participants.

pendent sample the inverted U-shape association between these two markers as shown previously (Erritzoe et al., 2010a; Fig. 5).

Demographics, radiotracer doses, and psychiatric symptom data are shown in Table 1 . The presurgical group had $\sim 60 \%$ higher BMI than the lean individuals $\left(t_{(27.9)}=15.27 ; p<0.0001\right.$, Welch's $t$ test). There was a trend for obese individuals having a lower education level than lean individuals $\left(t_{(11.2)}=1.90 ; p=\right.$ 0.08 , Welch's $t$ test $)$, but the intelligence scores were similar $(p=$ 0.59 , Mann-Whitney $U$ test). The injected dose per kilogram of body weight of $\left[{ }^{18} \mathrm{~F}\right]$ altanserin was $8 \%$ lower in the presurgical obese individuals than at rescan and in the lean individuals $(p<$ 0.001 ). No difference was found in the plasma-free fraction of $\left[{ }^{18} \mathrm{~F}\right]$ altanserin between obese individuals at baseline and lean or obese individuals before and after surgery $(p=0.27$ and $p=0.42$, respectively; Mann-Whitney $U$ test and Wilcoxon's test). The injected dose per kilogram of body weight of $\left[{ }^{11} \mathrm{C}\right] \mathrm{DASB}$ was lower in the presurgical obese group than in the lean individuals and also compared with the time of the postsurgery scan $\left(t_{(29.0)}=\right.$
Table 1. Demographics, radiotracer doses, and psychiatric symptom data of obese and lean participants

\begin{tabular}{llll}
\hline & Obese baseline & Obese rescans & Lean control \\
\hline$n$ (all included participants) & $21(4 \mathrm{men})^{a}$ & $14(2 \mathrm{men})^{b}$ & $10(3 \mathrm{men})$ \\
$\mathrm{BMI}\left(\mathrm{kg} / \mathrm{m}^{2}\right)$ & $40.1 \pm 4.1$ & $28.9 \pm 4.1$ & $24.6 \pm 1.5$ \\
Age (years) & $41.3 \pm 8.4$ & $43.1 \pm 8.4$ & $45.6 \pm 9.7$ \\
{$\left[{ }^{18} \mathrm{~F}\right]$ altanserin dose $(\mathrm{MBq} / \mathrm{kg})$} & $3.38(2.85-3.62)$ & $3.70(3.64-3.70)$ & $3.70(3.70-3.74)$ \\
{$\left[{ }^{18} \mathrm{~F}\right]$ altanserin $f_{\mathrm{p}}$} & $0.33(0.27-0.41)$ & $0.55(0.33-0.99)$ & $0.43(0.28-0.73)$ \\
{$\left[^{11} \mathrm{C}\right] \mathrm{DASB}$ dose $(\mathrm{MBq} / \mathrm{kg})$} & $5.00 \pm 0.86$ & $7.11 \pm 1.68$ & $8.43 \pm 1.36$ \\
Intelligence test $_{\text {Ed }}$ & $95.5(89.5-99.5)$ & $92.5(90.0-98.5)$ & $99.0(88.0-112.5)$ \\
Education (years in school) & $12.5 \pm 1.4$ & $11.9 \pm 1.0$ & $14.3 \pm 2.9$ \\
SCL-90-R (gsi) & $0.35 \pm 0.25$ & $0.21 \pm 0.20$ & $0.25 \pm 0.28$ \\
Cohen's perceived stress & $9.8 \pm 4.5$ & $9.7 \pm 5.0$ & $10.2 \pm 5.4$ \\
Major Depression Index & $7.9 \pm 5.3$ & $7.2 \pm 6.7$ & $5.1 \pm 2.9$ \\
\hline
\end{tabular}

Data are given as mean \pm SD or median with the interquartile range in parentheses depending on the distribution. $\left[{ }^{18} \mathrm{~F}\right]$ altanserin $f_{\mathrm{p}}$ is the plasma-free fraction of the parent compound. SCL-90-R (gsi) is a global measure of symptoms of psychopathology.

${ }^{a}$ In the $\left[{ }^{18} \mathrm{~F}\right]$ altanserin group, $n=20$ (4 men).

${ }^{b}$ In the $\left[{ }^{18} \mathrm{~F}\right]$ altanserin group, $n=12(2 \mathrm{men})$, and in the $\left[{ }^{11} \mathrm{C}\right] \mathrm{DASB}$ group, $n=13$ (2 men).

8.56, $p<0.001$ and $t_{(12.0)}=4.17, p=0.001$, respectively; paired and unpaired $t$ test). Age, gender distribution, and psychiatric scores were comparable between lean and obese individuals (all $p$ values $>0.21$, unpaired $t$ tests and $\chi^{2}$ test) except that a trend was observed ( $p=0.07$, Mann-Whitney $U$ test) for the obese individuals having more psychiatric symptoms as measured by the SCL-90-R than the lean individuals. However, all obese individuals scored well below the cutoff for caseness (1.08 in the Danish population; Olsen et al., 2006). The RYGB intervention was associated with a $25.8 \%$ reduction in BMI $t_{(13.0)}=6.9 ; p<0.0001$, paired $t$ test), but none of the psychiatric scores changed significantly with the weight loss ( $p$ values $>0.11$, Wilcoxon's test or paired $t$ tests).

Patients that underwent RYGB showed a significant increase in satiety and GLP- 1 compared with before RYGB ( $p=0.01$ and 0.002 , respectively; Wilcoxon's test). However, no correlation was found between the change in appetite scores or GLP-1 levels and the changes in BMI or the 5-HT marker changes after RYGB (all $p$ values $>0.084$ ).

\section{Discussion}

Here, we present significant associations between weight changes and the serotonergic neurotransmission in obese individuals, as measured in vivo with molecular brain imaging.

First, we found that neocortical $5-\mathrm{HT}_{2 \mathrm{~A}} \mathrm{R}$ binding predicted the size of the weight loss after RYGB (Fig. 1), and this suggests that the $5-\mathrm{HT}_{2 \mathrm{~A}} \mathrm{R}$ availability is a biomarker for the weight loss associated with gastric bypass. Interestingly, our data are supported by a recent study reporting that cerebral $5-\mathrm{HT}_{2 \mathrm{~A}} \mathrm{R}$ binding predicts body weight change in antipsychotic-naive schizophrenia patients when they initiate quetiapine treatment (Rasmussen et al., 2014). These observations suggest that cortical 5- $\mathrm{HT}_{2 \mathrm{~A}} \mathrm{R}$ can be regarded as being a risk marker of obesity and does not necessarily imply a primary role of $5-\mathrm{HT}_{2 \mathrm{~A}} \mathrm{R}$ in obesity. Our finding may have important implications for both surgical and nonsurgical management of obesity. Prediction of the long-term outcome after bariatric surgery is paramount to select the obese individuals, who have a limited effect of RYGB as the treatment is costly and can have severe side effects (Colquitt et al., 2014). If future studies confirm our finding, determination of the $5-\mathrm{HT}_{2 \mathrm{~A}} \mathrm{R}$ availability might become clinically important in separating the patients who will benefit from RYGB from those who are better treated nonsurgically.

The study also confirmed previous observations (Adams et al., 2004; Erritzoe et al., 2009) that obese individuals have signifi- 
cantly higher neocortical $5-\mathrm{HT}_{2 \mathrm{~A}} \mathrm{R}$ binding relative to lean individuals (Figs. 2, 3). According to Equation 1, our observation of higher $\mathrm{BP}_{\mathrm{P}}$ values in obese individuals can be attributable to three factors, or a combination thereof: (1) increased $\left.f_{\mathrm{P}}, 2\right)$ increased $B_{\text {avail }}$, or (3) decreased $K_{\mathrm{d}}$. We ruled out that there were differences in $f_{\mathrm{P}}$ between lean and overweight individuals. Since it seems less plausible that the affinity of the radioligand to $5-\mathrm{HT}_{2 \mathrm{~A}} \mathrm{R}$ binding sites should be related to BMI, a more likely interpretation is that the obese state is associated with a cerebral upregulation of $5-\mathrm{HT}_{2 \mathrm{~A}} \mathrm{Rs}$. Consistent evidence supports that the $5-\mathrm{HT}_{2 \mathrm{~A}} \mathrm{R}$ adjusts to the 5-HT level in the brain such that depletion of 5-HT levels results in increased 5- $\mathrm{HT}_{2 \mathrm{~A}} \mathrm{R}$ levels (Heal et al., 1985; Cahir et al., 2007) and that increased 5-HT levels after, for example, intake of SSRI or MDMA (3,4-methylenedioxymethamphetamine) results in reduction in $5-\mathrm{HT}_{2 \mathrm{~A}} \mathrm{R}$ binding (Spigset and Mjorndal, 1997; Meyer et al., 2001; Günther et al., 2008; Licht et al., 2009; Di Iorio et al., 2012; Urban et al., 2012). Therefore, we speculate that higher $5-\mathrm{HT}_{2 \mathrm{~A}} \mathrm{R}$ availability reflects lower 5-HT levels in obese individuals, leading to higher food intake. This interpretation is in line with the well known appetitesuppressing effect of central 5-HT (Donovan and Tecott, 2013).

The 5-HT-associated regulation of body weight might be of a more complex nature. Some obese individuals had comparable $5-\mathrm{HT}_{2 \mathrm{~A}} \mathrm{R}$ availability as lean individuals (Fig. 2), and we did not identify a simple postsurgical upregulation or downregulation of 5- $\mathrm{HT}_{2 \mathrm{~A}} \mathrm{R}$. Instead, in RYGB-treated individuals who experienced only a small weight loss, the $5-\mathrm{HT}_{2 \mathrm{~A}} \mathrm{R}$ was upregulated compared with before RYGB, and vice versa (Fig. 4). Interestingly, the exact same association was found for the 5-HTT. Given the inverse correlation between the 5- $\mathrm{HT}_{2 \mathrm{~A}} \mathrm{R}$ and 5-HT, one can interpret a high 5- $\mathrm{HT}_{2 \mathrm{~A}} \mathrm{R}$ availability as corresponding to low cerebral 5-HT. Given that low central 5-HT is associated with higher appetite (and vice versa; Lam et al., 2010), obese individuals with high $5-\mathrm{HT}_{2 \mathrm{~A}} \mathrm{R}$ may constitute a subgroup of overweight individuals characterized by a higher degree of deficient appetite, controlled through serotonergic mechanisms. Overweight individuals with normal 5- $\mathrm{HT}_{2 \mathrm{~A}} \mathrm{R}$ availability may have acquired their overweight through mechanisms unrelated to the 5 -HT system. In this context, we expected that the serotonergic markers would be related to satiety and GLP-1 and thereby feeding pattern. Even though we did find a significant increase in self-reported satiety and GLP-1 levels after a standard meal after RYGB in the obese group, we did not, however, find any association to serotonergic marker changes.

The observed relationship between $5-\mathrm{HT}_{2 \mathrm{~A}} \mathrm{R}$ binding and $\mathrm{BMI}$ could either reflect a direct role of this receptor in regulation of appetite and food intake, or it could be secondary to other changes in the serotonergic neurotransmission. However, the identical pattern of postsurgical regulation of the $5-\mathrm{HT}_{2 \mathrm{~A}} \mathrm{R}$ and the 5-HTT suggests that the same regulator influences the two 5-HT markers after RYGB. Moreover, we reproduced the inverted U-shaped relationship between neocortical $5-\mathrm{HT}_{2 \mathrm{~A}} \mathrm{R}$ binding and subcortical 5-HTT binding (Fig. 5), as described previously (Erritzoe et al., 2010a). This finding supports that within the single individual, the serotonergic markers have a set point that is adjusted through a common regulator, which is likely to be extracellular 5-HT levels determined by the output from the 5-HT-producing neurons in the raphé nucleus in the brain stem. Furthermore, because $5-\mathrm{HT}_{2 \mathrm{~A}} \mathrm{R}$ and 5-HTT binding conformed to the inverted U-shaped function after the RYGBinduced weight loss, this also supports that weight loss was not associated with selective $5-\mathrm{HT}_{2 \mathrm{~A}} \mathrm{R}$ or 5 -HTT regulation. These observations suggest that cortical $5-\mathrm{HT}_{2 \mathrm{~A}} \mathrm{R}$ can be regarded as being a risk marker of obesity and does not necessarily imply a primary role of $5-\mathrm{HT}_{2 \mathrm{~A}} \mathrm{R}$ in obesity.

We did not find differences between obese and lean and the levels of the 5-HTT as observed previously (Erritzoe et al., $2010 \mathrm{~b})$. A reason for that could be that the findings in the present study support that the association between 5-HTT and 5-HT is likely to be $\mathrm{U}$ shaped, given that the $5-\mathrm{HT}_{2 \mathrm{~A}} \mathrm{R}$ is correlated to 5 -HT in a negative feedback manner and to 5-HTT in an inverted U-shaped association. Therefore, group differences will be harder to prove and are even less meaningful.

Some strengths and limitations of this study need to be considered. The strengths were the longitudinal design combined with the concurrent measures of presynaptic and postsynaptic 5-HT markers. Hereby, the proposed model of central 5-HT levels as a common regulator underlying the postsurgical marker alterations and changes in BMI could be endorsed. Some potential limitations of our study should be mentioned. We did not include an obese control group that was rescanned after 8 months, without surgical intervention. However, given the reported consistency of $5-\mathrm{HT}_{2 \mathrm{~A}} \mathrm{R}$ upregulation in obesity, we do not expect that obese individuals with stable body weight would show any significant changes in their $5-\mathrm{HT}_{2 \mathrm{~A}} \mathrm{R}$ binding over a few years. Obviously, the weight reduction after RYGB varies over time, and we assessed the 5-HT system just at one time point after surgery. It has, however, been shown that the maximal weight reduction occurs after $\sim 9$ months (Sjostrom, 2008). Also, when we included time between RYGB and the follow-up PET scan as a covariate in the statistical models, the main outcome was unchanged. Because of differences in body weight, the presurgical obese individuals received a lower injected dose of $\left[{ }^{18} \mathrm{~F}\right]$ altanserin and $\left[{ }^{11} \mathrm{C}\right] \mathrm{DASB}$ per kilogram of body weight than lean individuals. This difference in injected radioligand dose is, however, taken into account when computing the binding potentials. That is, $\left[{ }^{18} \mathrm{~F}\right]$ altanserin brain binding is normalized against the steady-state plasma $\left[{ }^{18} \mathrm{~F}\right]$ altanserin concentration, and $\left[{ }^{11} \mathrm{C}\right] \mathrm{DASB}$ quantification uses a reference brain region as an indirect input function and is therefore independent of the plasma concentration of $\left[{ }^{11} \mathrm{C}\right] \mathrm{DASB}$. We also showed that the groupwise outcome of $\mathrm{BP}_{\mathrm{f}}$ was the same as for $\mathrm{BP}_{\mathrm{p}}$. Our observation of higher $\mathrm{BP}_{\mathrm{P}}$ values of $\left[{ }^{18} \mathrm{~F}\right]$ altanserin indicating higher $5-\mathrm{HT}_{2 \mathrm{~A}} \mathrm{R}$ availability in obese individuals can, according to Equation 1, be attributable to three factors, or a combination thereof: (1) increased $f_{\mathrm{P}},(2)$ increased $B_{\text {avail }}$, or (3) decreased $K_{\mathrm{d}}$. We ruled out that there were differences in $f_{\mathrm{P}}$ (the plasma-free fraction of the parent compound) between normal-weighted and overweight individuals. Since it seems less plausible that the affinity of the radioligand to $5-\mathrm{HT}_{2 \mathrm{~A}} \mathrm{R}$ binding sites should be related to BMI, a more likely interpretation is that the obese state is associated with a cerebral upregulation of $5-\mathrm{HT}_{2 \mathrm{~A}} \mathrm{Rs}$.

In this study, we found evidence for a modulatory role of the central 5-HT neurotransmission, in terms of extracellular 5-HT levels, contributing to the initial obese condition as well as to the subsequent regulation of body weight in response to RYGB. That is, we propose that it is the status of the serotonergic neurotransmission before RYGB that determines the weight loss achieved after RYGB rather than the change in body weight influencing the 5-HT system. It is, however, important to emphasize that the 5-HT system works in concert with multiple other factors such as diponectin, dopamine, endocannabinoids, ghrelin, leptin, nesfatin-1, norepinephrine, orexin, oxytocin, vasopressin, CCK, GLP-1, melanin-concentrating hormone, peptide YY, and stress hormones (Takahashi, 2010). As noted, we found a larger interindividual variability in neocortical $5-\mathrm{HT}_{2 \mathrm{~A}} \mathrm{R}$ binding in the pre- 
RYGB obese individuals compared with the lean individuals (Fig. 1), suggesting that some obese individuals have 5-HT levels comparable with lean individuals. Moreover, even with zero change in the 5-HT markers, a considerable RYGB-associated weight loss, in the order of $10 \mathrm{~kg} / \mathrm{m}^{2}$, was seen (Fig. 4). Therefore, this study underlines the diversity in obesity mechanisms and suggests that serotonergic neurotransmission plays a role in the context of multiple other mechanisms that also regulate changes in weight and that likewise are responsible for part of the RYGBinduced weight loss and possibly, to a varying degree, in different obese individuals. Clinically, our most important finding here was the value of presurgical levels of cerebral $5-\mathrm{HT}_{2 \mathrm{~A}} \mathrm{R}$ to predict the 8-month outcome of RYGB. Though costly, it is possible that cerebral $5-\mathrm{HT}_{2 \mathrm{~A}} \mathrm{R}$ PET scans could be indicated before bariatric surgery to save the personal and societal costs of unsuccessful RYGB. Future studies should explore these possibilities.

\section{References}

Adams KH, Pinborg LH, Svarer C, Hasselbalch SG, Holm S, Haugbøl S, Madsen K, Frøkjaer V, Martiny L, Paulson OB, Knudsen GM (2004) A database of [(18)F]-altanserin binding to 5-HT(2A) receptors in normal volunteers: normative data and relationship to physiological and demographic variables. Neuroimage 21:1105-1113. CrossRef Medline

Asarian L (2009) Loss of cholecystokinin and glucagon-like peptide-1induced satiation in mice lacking serotonin $2 \mathrm{C}$ receptors. Am J Physiol Regul Integr Comp Physiol 296:R51-R56. CrossRef Medline

Berthoud HR, Zheng H, Shin AC (2012) Food reward in the obese and after weight loss induced by calorie restriction and bariatric surgery. Ann N Y Acad Sci 1264:36-48. CrossRef Medline

Cahir M, Ardis T, Reynolds GP, Cooper SJ (2007) Acute and chronic tryptophan depletion differentially regulate central 5-HT1A and 5-HT 2A receptor binding in the rat. Psychopharmacology (Berl) 190:497-506. CrossRef Medline

Colquitt JL, Pickett K, Loveman E, GK F (2014) Surgery for weight loss in adults. Cochrane Database Syst Rev 8:CD003641. CrossRef Medline

Di Iorio CR, Watkins TJ, Dietrich MS, Cao A, Blackford JU, Rogers B, Ansari MS, Baldwin RM, Li R, Kessler RM, Salomon RM, Benningfield M, Cowan RL (2012) Evidence for chronically altered serotonin function in the cerebral cortex of female 3,4-methylenedioxymethamphetamine polydrug users. Arch Gen Psychiatry 69:399-409. CrossRef Medline

Docherty NG, le Roux CW (2014) Improvements in the metabolic milieu following Roux-en-Y gastric bypass and the arrest of diabetic kidney disease. Exp Physiol 99:1146-1153. CrossRef Medline

Donovan MH, Tecott LH (2013) Serotonin and the regulation of mammalian energy balance. Front Neurosci 7:36. CrossRef Medline

Erritzoe D, Frokjaer VG, Haugbol S, Marner L, Svarer C, Holst K, BaaréWF, Rasmussen PM, Madsen J, Paulson OB, Knudsen GM (2009) Brain serotonin $2 \mathrm{~A}$ receptor binding: relations to body mass index, tobacco and alcohol use. Neuroimage 46:23-30. CrossRef Medline

Erritzoe D, Holst K, Frokjaer VG, Licht CL, Kalbitzer J, Nielsen FA, Svarer C, Madsen J, Knudsen G (2010a) A nonlinear relationship between cerebral serotonin transporter and $5-\mathrm{HT}_{2 \mathrm{~A}}$ receptor binding: an in vivo molecular imaging study in humans. J Neurosci 30:3391-3397. CrossRef Medline

Erritzoe D, Frokjaer VG, Haahr MT, Kalbitzer J, Svarer C, Holst KK, Hansen DL, Jernigan TL, Lehel S, Knudsen GM (2010b) Cerebral serotonin transporter binding is inversely related to body mass index. Neuroimage 52:284-289. CrossRef Medline

Günther L, Liebscher S, Jähkel M, Oehler J (2008) Effects of chronic citalopram treatment on 5-HT1A and 5-HT2A receptors in group- and isolation-housed mice. Eur J Pharmacol 593:49-61. CrossRef Medline

Haahr ME, Rasmussen PM, Madsen K, Marner L, Ratner C, Gillings N, Baaré W, Knudsen GM (2012) Obesity is associated with high serotonin 4 re- ceptor availability in the brain reward circuitry. Neuroimage 61:884-888. CrossRef Medline

Haahr ME, Fisher PM, Jensen CG, Frokjaer VG, Mahon BM, Madsen K, Baaré WF, Lehel S, Norremolle A, Rabiner EA, Knudsen GM (2014) Central 5-HT4 receptor binding as biomarker of serotonergic tonus in humans: a [11C]SB207145 PET study. Mol Psychiatry 19:427-432. CrossRef Medline

Heal DJ, Philpot J, Molyneux SG, Metz A (1985) Intracerebroventricular administration of 5,7-dihydroxytryptamine to mice increases both headtwitch response and the number of cortical 5-HT2 receptors. Neuropharmacology 24:1201-1205. CrossRef Medline

Ichise M, Liow JS, Lu JQ, Takano A, Model K, Toyama H, Suhara T, Suzuki K, Innis RB, Carson RE (2003) Linearized reference tissue parametric imaging methods: application to [11C]DASB positron emission tomography studies of the serotonin transporter in human brain. J Cereb Blood Flow Metab 23:1096-1112. CrossRef Medline

Lam DD, Garfield AS, Marston OJ, Shaw J, Heisler LK (2010) Brain serotonin system in the coordination of food intake and body weight. Pharmacol Biochem Behav 97:84-91. CrossRef Medline

le Roux CW, Welbourn R, Werling M, Osborne A, Kokkinos A, Laurenius A, Lönroth H, Fändriks L, Ghatei MA, Bloom SR, Olbers T (2007) Gut hormones as mediators of appetite and weight loss after Roux-en-Y gastric bypass. Ann Surg 246:780-785. CrossRef Medline

Licht CL, Marcussen AB, Wegener G, Overstreet DH, Aznar S, Knudsen GM (2009) The brain 5-HT4 receptor binding is down-regulated in the Flinders Sensitive Line depression model and in response to paroxetine administration. J Neurochem 109:1363-1374. CrossRef Medline

Meyer JH, Kapur S, Eisfeld B, Brown GM, Houle S, DaSilva J, Wilson AA, Rafi-Tari S, Mayberg HS, Kennedy SH (2001) The effect of paroxetine on 5-HT(2A) receptors in depression: an [(18)F] setoperone PET imaging study. Am J Psychiatry 158:78-85. CrossRef Medline

Olesen O, Sibomana M, Keller S, Andersen F, Jensen J, Holm S, Svarer C, Højgaard L (2009) Spatial resolution of the HRRT PET scanner using 3D-OSEM PSF reconstruction. IEEE Nucl Sci Symp Conf Rec 3789-3790.

Olsen LR, Mortensen EL, Bech P (2006) Mental distress in the Danish general population. Acta Psychiatr Scand 113:477-484. CrossRef Medline

Orskov C, Rabenhøj L, Wettergren A, Kofod H, Holst JJ (1994) Tissue and plasma concentrations of amidated and glycine-extended glucagon-like peptide I in humans. Diabetes 43:535-539. CrossRef Medline

Pi-Sunyer X (2009) The medical risks of obesity. Postgrad Med 121:21-33. CrossRef Medline

Rasmussen H, Ebdrup BH, Oranje B, Pinborg LH, Knudsen GM, Glenthøj B (2014) Neocortical serotonin2A receptor binding predicts quetiapine associated weight gain in antipsychotic-naive first-episode schizophrenia patients. Int J Neuropsychopharmacol 17:1729-1736. CrossRef Medline

Ratner C, Ettrup A, Bueter M, Haahr ME, Compan V, le Roux CW, Levin B, Hansen HH, Knudsen GM (2012) Cerebral markers of the serotonergic system in rat models of obesity and after Roux-en-Y gastric bypass. Obesity (Silver Spring) 2:2133-2141. CrossRef Medline

Sjostrom L (2008) Bariatric surgery and reduction in morbidity and mortality: experiences from the SOS study. Int J Obes (Lond) 32 [Suppl 7]: S93-S97. CrossRef Medline

Spigset O, Mjorndal T (1997) Effect of fluvoxamine on platelet 5-HT2A receptors as studied by $[3 \mathrm{H}]$ lysergic acid diethylamide $([3 \mathrm{H}] \mathrm{LSD})$ binding in healthy volunteers. Psychopharmacology (Berl) 133:39-42. CrossRef Medline

Takahashi T (2010) Toward molecular neuroeconomics of obesity. Med Hypotheses 75:393-396. CrossRef Medline

Urban NB, Girgis RR, Talbot PS, Kegeles LS, Xu X, Frankle WG, Hart CL, Slifstein M, Abi-Dargham A, Laruelle M (2012) Sustained recreational use of ecstasy is associated with altered pre and postsynaptic markers of serotonin transmission in neocortical areas: a PET study with [(1)(1)C]DASB and [(1)(1)C]MDL 100907. Neuropsychopharmacology 37:1465-1473. CrossRef Medline 